\title{
The digital model as a key tool for preserving architectural heritage in strategic master planning
}

\author{
Svetlana Maksimova*, Anastasia Semina, Anna Shamarina and Anna Balandina \\ Perm National Research Polytechnic University, 29, Komsomolsky prospekt, Perm 614990, Russia
}

\begin{abstract}
The possibilities and role of a three-dimensional spatial model are considered on the example of the historical and architectural Usolye Stroganovsky museum-reserve strategic master plan (Perm region). In the context of heritage preservation, the master plan was shown not only as a strategic document, but also as a communication tool between various branches of government in order to integrate heritage protection policy into the system of general urban planning policy. The methodological approach is based on use of a digital three-dimensional model obtained by laser scanning and photogrammetry. A portable and ground-based laser scanning to create the point cloud is presented. The architectural and urban planning solutions of the strategic master plan are based on the dynamic 3D model and static visualizations of individual elements. The results of virtual reconstruction are shown. The level of detail of 3D models is LOD 200. Virtual reconstruction and visualization have shown themselves not only as a reliable communication tool for the decision-making management, but also as a way to quickly obtain a complex of urban planning and design documentation suitable for reconstruction and restoration of historical and architectural heritage.
\end{abstract}

\section{Introduction}

One of the significant tasks of the state cultural policy in the field of cultural heritage is the preservation of the historical environment of small towns and the establishing conditions for the development of cultural tourism in Russian Federation. Usolye town (Perm Krai) urgently needs the development of effective measures that will be able to popularize its cultural and tourist opportunities, and will be able to develop the economy of the settlement.

The architectural forms of the Usolsky historical and architectural complex (museumreserve) represent two "golden ages" of stone architecture in New Usolye: the Russian (Muscovite) uzorochye of the 18th century's first third and the 19th century's Russian classicism era. Architectural heritage includes 43 objects of religious and civil architecture of different significance and conditions of preservation (Fig. 1).

* Corresponding author: svetlana-maximova@yandex.ru 
Usolye is located on a vast low-lying area, on a bank of the waterway (Kama River) with several branches-channels. Such position of the town determines its planning character as well as the appearance of architectural and landscape panoramas. Currently, the unique architectural and landscape potential of the territory is not used, as it requires planning organization and filling with recreational functions that help to increase the attractiveness of the museum for residents and tourists (Fig. 2).

This article describes an approach to the development of a strategic master plan of the territory enriched architectural heritage. The planning strategy is aimed at solving a dual task: development strategy elaboration for another 15-20 years of the museum-reserve and the disappearing historical environment virtual representation. This approach is based on a territory comprehensive survey using digital tools (laser scanning, aerial photography, and photogrammetry) and creating its 3D-model, which in the working process of a master plan development became the basis for consultations with experts and public discussions and decision-making.

Section 2 of the article is focused on the theory and methodology of 3D-visualization based on a digital survey of Usolye architectural monuments for the strategic master plan solutions. Section 3 provides examples of the reconstruction and representation of architectural monuments of various preservation conditions in a digital format. The final section is devoted to the role of digital visualization in the development of urban planning documentation of historical and architectural heritage.

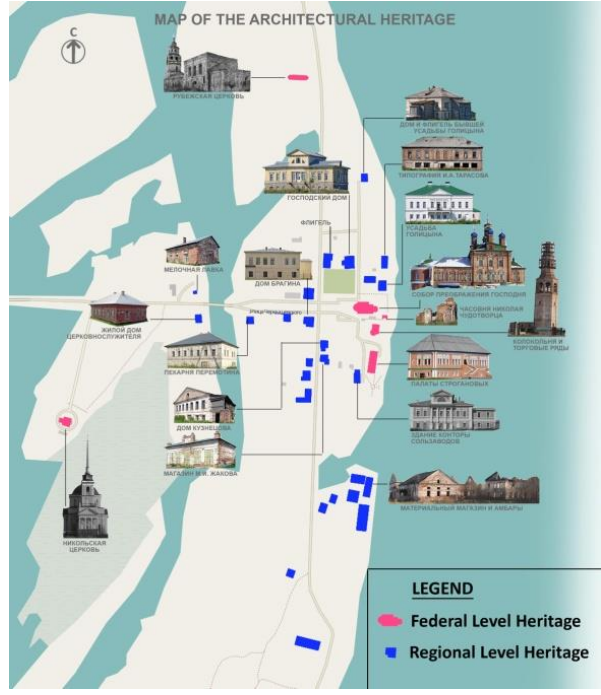

Fig. 1.Schematic map of the location of cultural heritage sites in Usolye and their significance.

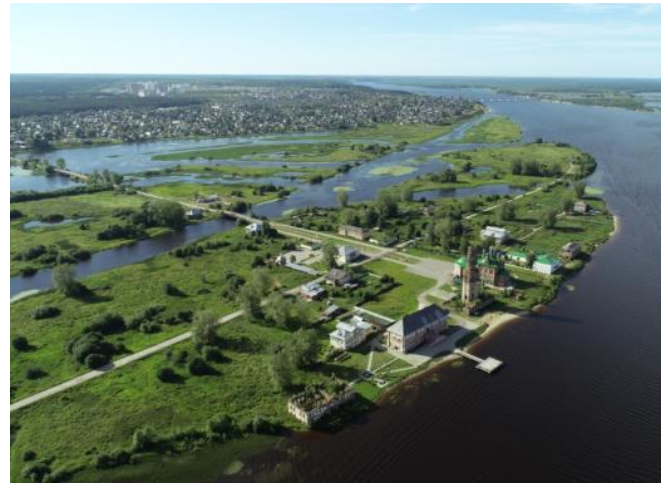

Fig. 2. View on the historical part of Usolye. Photo of 2019 .

\section{Theory and methodology}

Strategic master planning is a traditional tool for territorial planning; however, in Russia it has rather slowly been established. Russian urban planning practice largely retains the Soviet approach features, which was based on the priority of the spatial architectural plan (land use) over the economic strategy and a centralized regulatory framework [1]. Discussions about promotion of the strategic master plan as an obligatory territorial planning document are enhanced, but have not yet reached the legislative level. 
Time and economic factors make their own adjustments and gradually the heads of municipalities come to the development of strategic master plans $[2,3]$ and to the implementing of master planning tools: mechanisms of "advocacy planning" and "participatory design", the practice of public discussions, etc. [4, 5]. The strategic master plan of Usolsky Museum-Reserve preservation was considered not only as a long-term strategic document, but also as a communication tool between various branches of the government in order to integrate the heritage protection policy into the system of general urban planning policy for the aims of the preservation and advancement of the Usolye historical environment [6]. The virtual reconstruction of the territory was the basis for communication and the reconstruction strategy identification as well as the museum's next 15 years development, technical and economic assessment.

Abroad, the topic of architectural heritage virtual reconstruction came up at the turn of the 1990s-2000s. [7, 8]. Foreign experience in the field of 3D modelling contains a number of virtual reconstructions examples of various architectural monuments, historical buildings and historical landscapes [9]. These examples include a computer reconstruction of the 10th century Abbey of Cluny, carried out by the Saone-et-Loire department in France as part of the ClunyIII project [10], and a project for the reconstruction of Rome [11].

In Russia, the topic of 3D modelling in the field of architectural monuments reconstruction became interesting a little later $[12,13,14]$. Initially, the topic of virtual reconstruction became relevant in the field of digital humanities among historians, archaeologists and restorers. Currently, there are articles describing the work on the reconstruction and representation of architectural objects in digital three-dimensional form. Examples are the project "Virtual Reconstruction of the Transfiguration Monastery in the city of Yeniseisk in the 19th century" [15, 16], reconstruction of the Cherdyn Kremlin [17], and reconstruction of the lost monuments of the Tambov fortress [18]. However, the experience of using the virtual reconstruction technology and representation based on digital three-dimensional models for the tasks of territorial and strategic master planning is still insufficient in Russia.

The methodological approach to the strategic master plan development was based on the objectives of the work and the special features of the territory. It included the visualisation of museum development strategy in the form of a three-dimensional model, which greatly facilitated interaction with experts, residents and stakeholders. Along with a preliminary context analysis and collection archive materials, a complex landscape-visual analysis [19] was carried out to identify the levels of reading the environment and the main physical objects of interest for reconstruction and development. The survey of the landscape was carried out by the methods of photogrammetry, mapping and spherical panoramas.

Digital technologies survey (laser scanning, aerial photography, photogrammetry) were used to obtain three-dimensional data with a geospatial reference. Two types of laser scanners were used: a stationary laser scanner Leica Scan station S10 (more accurate scanning of architectural objects) and a portable laser scanner KAARTA (fast landscape scanning over a large area) in order to obtain the most complete point clouds sets forthe subsequent 3D modelling.

The digital strategic master plan model was created using several software systems for $3 \mathrm{D}$ modelling and visualization. For processing photogrammetric data and laser scanning data were used Cyclone 8, CloudCompare, Agisoft Photoscan; for modelling buildings, landscapes and transport infrastructure - ArchiCAD 22. The level of detail of the digital model elements (the minimum amount of geometric, spatial, quantitative, attribute data) corresponds to LOD 200. Three-dimensional models of buildings and landscapes were imported into the Lumion 8 environment from ArchiCAD using export to the extension dae. Static and dynamic visualizations were made in order to represent a general idea of the territory, define architectural dominants, reconcile the architectural and urban planning 
solutions and observe the result. Adobe Photoshop CS5 and Lumion 8 software were used to create static and dynamic visualizations of the complex.

\section{Representation and reconstruction of architectural monuments in digital format}

The development scenario for the Usolye Stroganovsky Museum-Reserve is aimed at preserving the uniqueness of the architectural heritage complex, associated with the famous Russian surname of the Stroganov in addition to transforming the environment into a modern historical and cultural cluster.

The few preserved fragments of streets, buildings and the main square in front of the Transfiguration Cathedral formed the planning basis for the 2020 strategic master plan. Cultural heritage objects were divided into 3 groups: ruins to be preserved, objects in a maintainable condition and functioning buildings. Some objects were of the greatest interest from the point of view of general views visualization and presentation, such as: restored monuments; investment sites for new buildings required for museum development (and their volumes); landscape transformation and urban equipment elements. The main principle of architectural and planning concept is the harmonic interaction of new buildings and objects of the urban environment with heritage and the existing urban planning organization.

All objects were modelled and placed on a digital terrain of the territory, which was created by extracting from the point cloud obtained by scanning with a portable scanner the structure of the earth's surface, relief, roads and other details (Fig. 3).

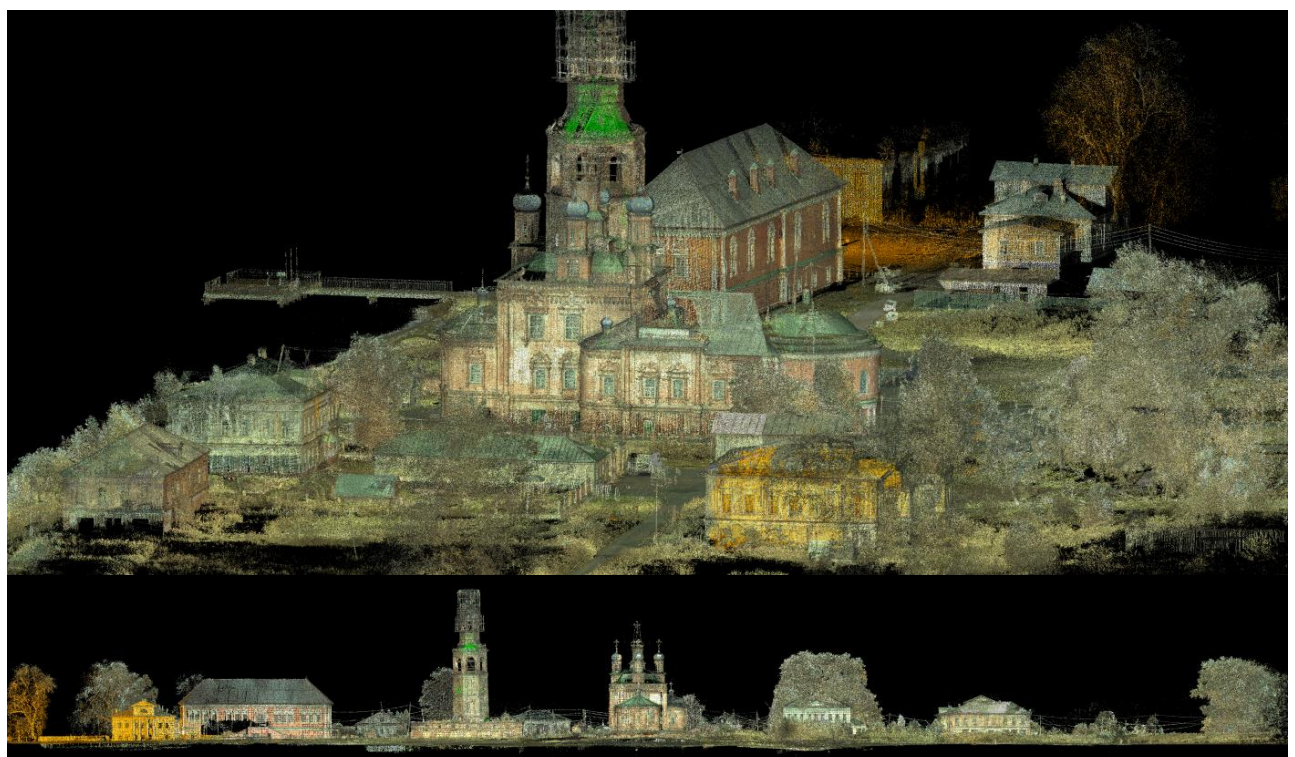

Fig. 3. Point cloud of the complex central part.

3D-modeling of the particular architectural monuments in the ArchiCAD environment was carried out according to different scenarios due to sets of initial information for each building. A detailed point cloud of the functioning Transfiguration Cathedral (1731) was obtainedusing ground-based laser scanning. In combination with historical photos and drawings it allows to recreate the building with great accuracy (Fig. 4). 


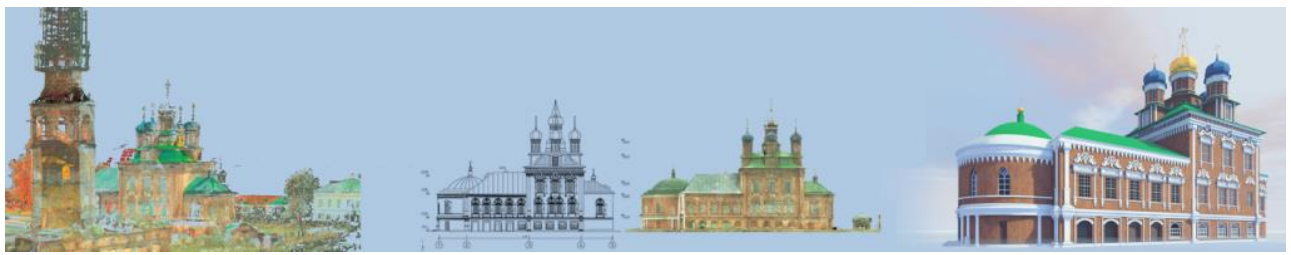

Fig. 4. Modelling of the UsolyeTransfiguration Cathedral.

Modelling the ruined objects used only archival photographs. In this case, the dimensions of the building parts were determined based on the known dimensions of the elements, for example, bricks. If there are dimensional drawings in the archive, they were used as a background in the ArchiCAD working window (Fig. 5).

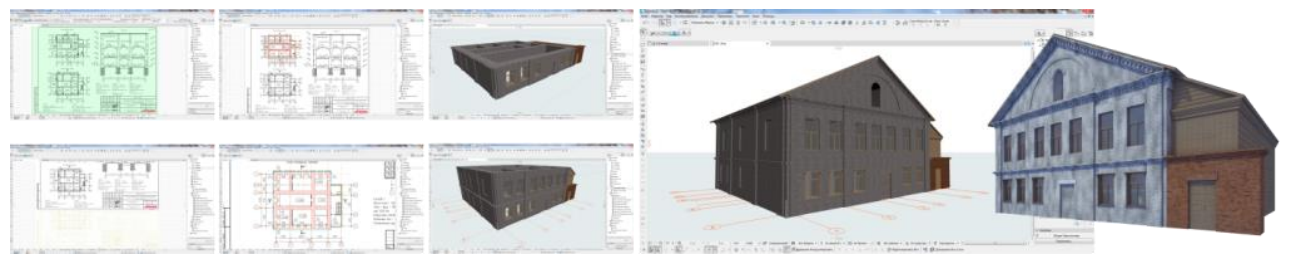

Fig. 5. Virtual reconstruction of the I. Kuznetsov'shouse.

A total 30 models of architectural monuments of the historical complex were created using various methods of virtual reconstruction. Some objects are modelled in their current (ruined) state. Others have been recreated in their original form to demonstrate how the complex might look after reconstruction (Fig. 6, Fig. 7).
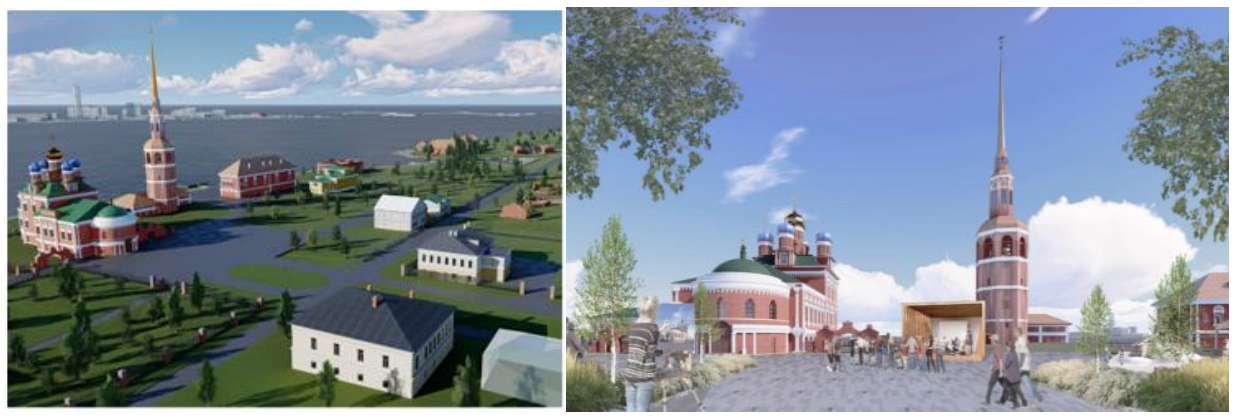

Fig. 6. 3D model of the main square of the museum reserve.

Dynamic and static versions museum complex visualization were created based on the obtained digital three-dimensional model of the territory. The colour and light correction of images and adding of stuffing in Adobe Photoshop was used to improve the quality of visualizations (Fig. 8). Static visualizations allowed to present proposals for transforming objects, which will play a decisive role in the overall process of implementing the master plan. 


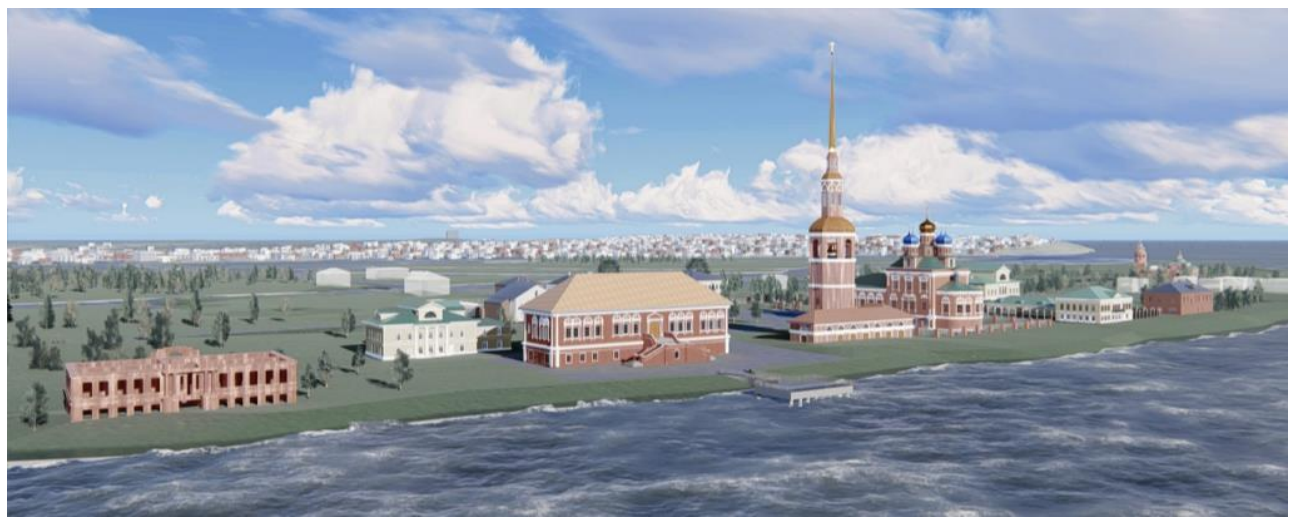

Fig. 7. 3D model of the historical and architectural complex Usolye Stroganovsky.

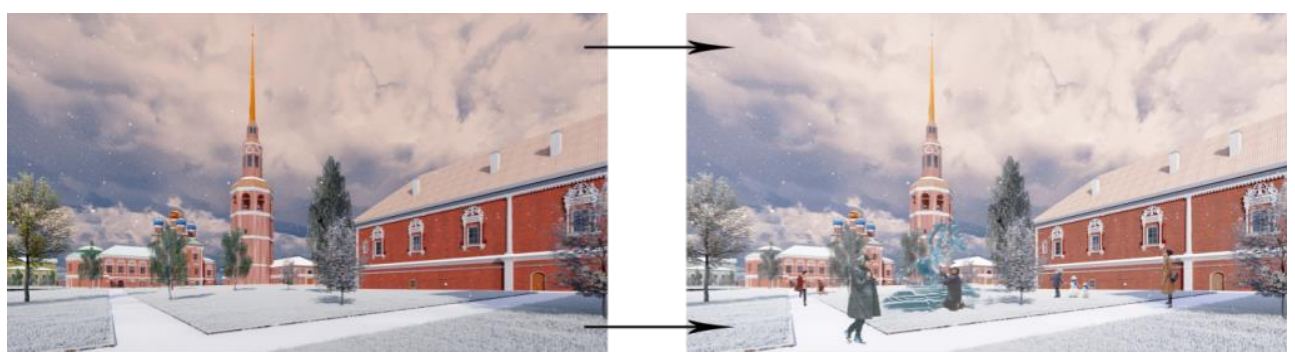

Fig. 8. View of the bell tower BEFORE and AFTER processing in Adobe Photoshop.

Static visualizations show a qualitatively new level of public spaces and landscapes transformation of the Museum-Reserve in the forms of the Central Museum Core (the main square in front of the Transfiguration Cathedral); Embankment, the Lord's House, the Refectory and the Park of Ruins, Bogorodskaya Street, the Restored Bell Tower (Fig. 9).

The key projects visualization is necessary in order to get public support and a loyal responsible attitude by the residents, business and public authorities towards the implementation of the strategic master plan. Subsequently the key projects implementation will demonstrate the Administration's focus on results, inspire investors and create favourable conditions for continuing work for further territory renovation.
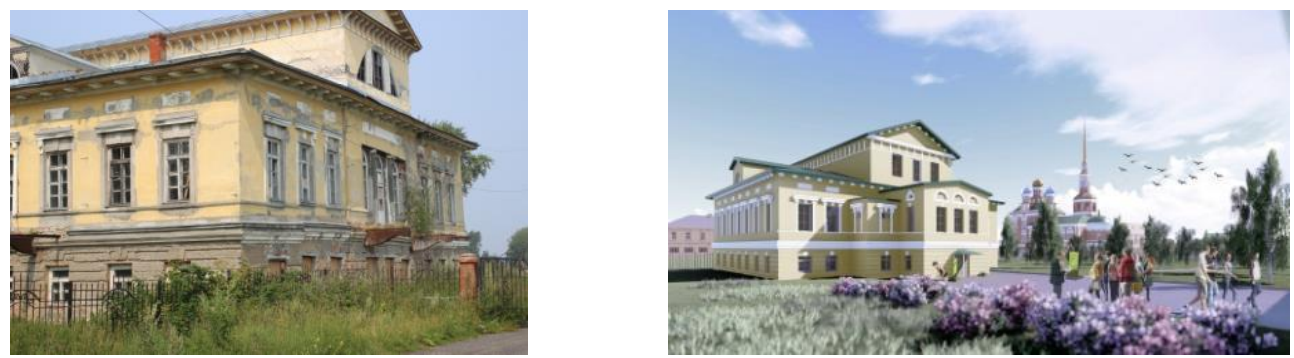

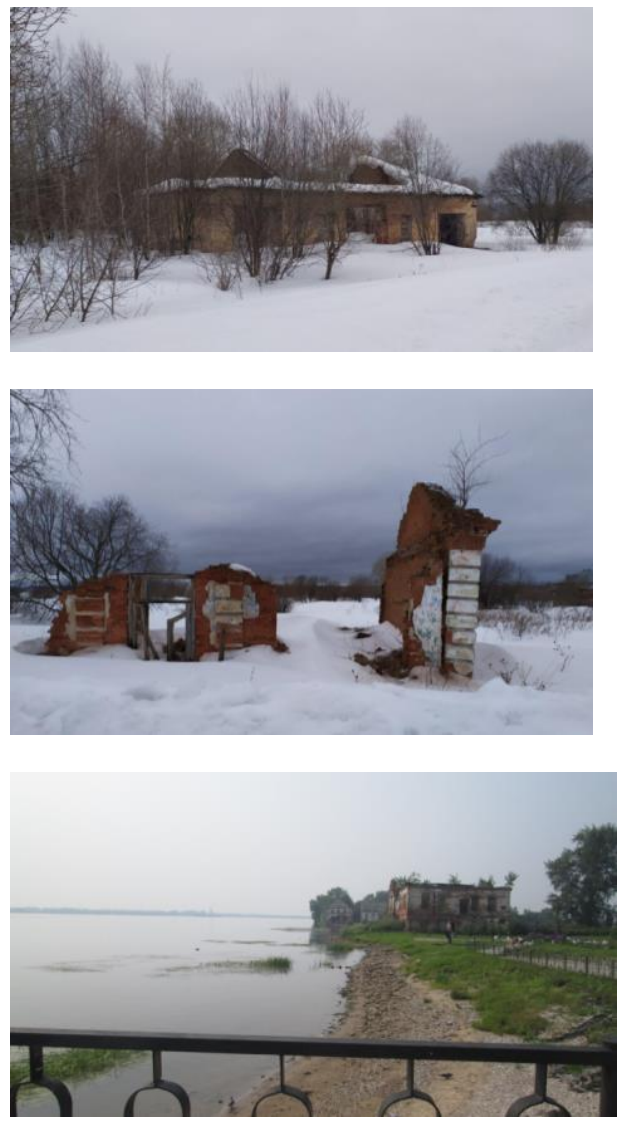

Fig. 9. Comparison of the current views and the results of the individual objects and key public spaces virtual reconstruction.

\section{Conclusions and discussion}

The digital model of the Usolsky Museum-Reserve proved to be a universal tool for the strategic master plan development. Its main tasks were solved with the help of this strategy: spatial organization with socio-cultural content, sequence of engineering and technical measures related to the preservation of the museum fund. The visualization of the strategy allowed demonstrating the solutions and harmonizing the points of view of various stakeholders: the municipality, the heritage protection service, museum staff and residents.

The potential of Usolye as a unique place for the Upper Kama region development can be unleashed only in the conditions of the acceptance of the strategic master plan ideas by residents as well as inclusion of all levels of government and patriotically responsible business in solving problems process. High-quality design documentation based on the digital model of the complex will help the City Administration to find forms of interaction with large companies, for which the financial support of the Usolsky architectural complex can become a symbol of social responsibility and patriotism.

A comprehensive 3D model of the territory is now a source of complete design documentation for the reconstruction and renovation of cultural heritage sites. Subsequently the transfer of the model to BIM and to the 3D GIS environment opens up new possibilities for the monitoring, management and analysis the unstable hydrological situation in Usolye, ruined and in-use heritage objects, planning repairs, etc. 
Because some of the museum-reserve objects were lost during the historical evolution of the territory and there are certain difficulties in obtaining funding for the construction of a modern museum in the status of a municipal institution, the digital model of the territory will allow wider implementation of modern museum technologies [20].

Virtual museum, interactive multimedia installations, self-guided tours with a QR code or an audio guide, expanding the presence on social networks and the Internet will increase the audience of the museum and create additional motivation to visit it.

In the Usolsky Museum-Reserve strategic master plan elaboration the virtual reconstruction and visualization proved to be not only a reliable communication tool in the process of making management decisions, but also a way to quickly obtain a complex of full-fledged project documentation suitable for reconstruction and restoration of historical and architectural heritage, preservation of disappearing historical monuments for future generations. The last point has great importance for remote settlements and villages which have difficulties in financing restoration work.

Summarizing the experience of developing a strategic master plan for the Usolye architectural complex, it can be stated that the use of digital models should become the basic component of the entire heritage protection system: from strategic master plans to protection zones projects and working documentation of individual objects.

Information technology is confidently entering all areas of construction and architecture. Urban planning documentation can no longer be developed without geoinformation technologies, architectural and construction documents - without building information models. The next step in improving urban planning, architectural and construction documentation is the introduction of the digital survey and three-dimensional modelling in the field of heritage protection.

This work was carried out with the support of PROMETHEUS project funding EU program Horizon 2020-R\&I-RISE-Research \& Innovation Staff Exchange Marie Skłodowska-Curie grant agreement No 821870 .

\section{References}

1. M. Meerovich, About Methodology and Ideology of Historical Research on Soviet Architecture and Town Planning, Project Baikal, 11 (42), 10-13 (2014)

2. A.S. Korolev, E.P. Danilenko, T.G. Kalachuk, Strategic Master Plan For The Establishment Multipark Of Belgorod Agglomeration, Bulletin of Belgorod State Technological University named after. V. G. Shukhov, 6, 35-39 (2015)

3. V.P. Stepanov, A.V. Galeev, S.V. Shklyaev, P.E. Manokhin, Master-Plan As Structurally-Functional Model Town-Planning Development Of The City, Fotinskie chteniya, 1 (9), 429-435 (2018)

4. K.S. Afanassiev, Problems Of Optimizing The Strategic Planning System At The Municipal Level, Economy of the new world, 3, 69-86 (2016)

5. S.D.Mitiagin, General (Master) Plans Of Settlements Under New, Industrial And Civil Engineering, 9, 76-81 (2019)

6. S. Maksimova, A. Maksimov, Revival of historical and architectural heritage as a way to develop a post-Soviet industrial town, Proceeding of 56th ISOCARP World planning congress, ISBN/EAN 978-90-75524-67-3, 770-781 (2020)

7. D. Koller, J. Trimble, T. Najbjerg, N. Gelfand, M. Levoy, Fragments of the City: Stanford's Digital Forma Urbis Romae Project, Proceedings of the Third 
Williams Symposium on classical Architecture, Journal of Roman Archaeology, 61, 237-252 (2006)

8. N.A. Haddad, From Ground Surveying to 3D Laser Scanner: A Review of Techniques Used for Spatial Documentation of Historic Sites, Journal of King Saud University Engineering Sciences, 2, 109-18 (2011). doi:10.1016/j.jksues.2011.03.001.

9. S. Parrinello, F. Picchio, R. De Marco, 2017Pavia 3D: reading and decomposition of the city for the construction of dynamic databases on heritage, Applied ecology. Urban development, PNRPU, 1, 33-45 (2017)

10. C. Père, J. Landrieuet, J. Rollier-Hanselmann, Reconstitution virtuelle de l'église abbatial le Cluny III: des fouilles archéologiques aux algorithmes de l'imagerie, Virtual Retrospect, 151-159 (2009)

11. Plan de Rome: site. URL: https://rome.unicaen.fr/ (accessed: 15.02.2021)

12. V.V. Moor, Ispol'zovanie metodov arhitekturnogo komp'yuternogo modelirovaniya dlya rekonstrukcii arheologicheskih ob'ektov, Information bulletin of the Association "History and Computer", 20-21 (2010)

13. M.S. Mironenko, P.S. Mironenko, Virtual 3D reconstruction Of The Cathedral Of Michaels Archangel Miracle Monastery Of The Moscow Kremlin, Istor. Inform., 1, 2840 (2013)

14. M.N. Anikushin, A.V. Leonov, Lazernoe Skanirovanie I 3D-Modelirovanie Shuhovskoj Bashni Na Shabalovke, Trimetari Consulting, Online. URL: http://rimetari.com/ru/proekty/lazernoe-skanirovanie-i-3d- modelirovanie-shuhovskojbashni-na-shabolovke (accessed: 15.02.2021)

15. Historical and cultural heritage of the city of Yeniseisk: site. URL: https://www.yeniseisk-heritage.ru / (accessed: 29.04.2020)

16. M. Rumyantsev, A. Smolin, R. Baryshev, I. Rudov, N. Pikov, Virtual Reconstruction Of Historical And Cultural Heritage Objects, Information bulletin of the Association "History and Computer", 175-197 (2010)

17. P.A. Korchagin, K.V. Plotnikov, Virtual 3d Reconstruction And Natural Reconstruction Of The Cherdyn Kremlin Of XVI-XVIII Centuries, Digital Humanities: Resources, Methods, Research Proceedings of a Scientific Conference, Publisher: Perm State Research University (Perm), 29-32 (2017)

18. D.I. ZHerebyat'ev, Primenenie Tekhnologij Interaktivnogo Tryohmernogo Modelirovaniya Dlya Vosstanovleniya Utrachennyh Pamyatnikov Istorii I Arhitektury (Na Primere Tambovskoj Kreposti), Information bulletin of the Association "History and Computer", 321-342 (2008), URL: http://www.aik-sng.ru/text/krug/8/321-342.pdf (accessed: 15.02.2021)

19. A. E. Kuznetsova, J. V. Bushmakova, Survey Of riversides Landscapes In The City Of Usolye, PNRPU. Applied ecology. Urban development, 1, 69-79 (2017)

20. T.A. Smirnova, Muzej V 21 Veke: Integraciya Cifrovyh Tekhnologij V Ekspozicionnoe Prostranstvo, Informacionnoe obshchestvo, 4, 55-61 (2012) 